\title{
23 Research Square \\ Infection of the Parasitic Isopods on Commercial Fishes of the Northern Part of the East Coast of India
}

Dipanjan Ray ( $\sim$ dipanjan2010@gmail.com )

Bajkul Milani Mahabidyalaya

Parnasree Mohapatra

University of Calcutta

Narayan Ghorai

West Bengal State University

Jaya Kishor Seth

Berhampur University

Anil Mohapatra

Zoological Survey of India

Research Article

Keywords: Isopod parasites, commercial fishes, prevalence, seasonal variation

Posted Date: November 9th, 2021

DOI: https://doi.org/10.21203/rs.3.rs-912575/v1

License: (9) (i) This work is licensed under a Creative Commons Attribution 4.0 International License. Read Full License 


\section{Abstract}

The present study report the parasitic isopod infection on commercial fishes of the northern part of the east coast of India collected during the period 2010-2015 from the marine water of Odisha and West Bengal. During the study, 394 isopods were collected after examining 2668 fishes. These include 14 species of isopods, out of which 13 belong to 5 genera under the family Cymothoidae, and a single species Alitropus typus belongs to the family: Aegidae. Of theses, 03 species viz., Catoessa boscii, Cymothoa eremita and Nerocila loveni are first record to the northern part of east coast of India. Out of the 2668 fishes examined, 326 examples belonging to 34 species under 19 different families were infected by different isopods. Member of the host fish family Carangidae was more parasitized by isopods, followed by Clupeidae, Scoberidae, and Leiognathidae. The dominant isopods were Nerocila phaiopleura and Catoessa boschii. The total prevalence was 12.21. The prevalence was high on the host fish Alepes djedaba and lowest on Lutjanus johnii. The total infection caused by genus Alitropus was $1.52 \%$, Anilocra was $5.07 \%$, Catoessa was $24.87 \%$, Cymothoa was $0.25 \%$, Nerocila was $65.73 \%$, and Norileca was $2.55 \%$. The isopod prevention was high during the post-monsoon and low during the monsoon period.

\section{Introduction}

The parasitic isopods usually occur in the freshwater, estuarine and marine ecosystem, especially near the coastal environment. In these ecosystems, they play an essential role in the ecological food chain and removal of the decaying matter (Bharadhirajan 2014). Besides this ecological role, the study of these isopods is also important as they cause a range of damages to the fishes, thereby threatening the fisheries sector (Mohapatra et al. 2021; Seth et al. 2020 a, b; 2021). Out of the 144 known isopod families, only a few are parasitic. The family Cymothoidae is one of the most prominent families of the order Isopoda. The representative of the family is the obligate parasites, known to show a high degree of the host and site-specificity to the host fishes Ravichandran et al. (2019). However, in some species, host specificity is weak.

The family Cymothoidae consists of more than 380 species under 43 genera worldwide (Smith et al. 2014). Of these, 48 valid species under 16 genera are reported from Indian water (Ravichandran et al.2019). The adult forms of the family Aegidae White, 1850 of the order Isopoda, are considered temporary parasites as they often leave their host after a blood meal. Due to this nature, they have been recently classified as free-living micropredators (Ravichandran et al. 2019). The family Aegidae includes around 152 species under 8 genera worldwide (Al-Zubaidy and Mhaisen 2014). The genus Alitropus $\mathrm{H}$. Milne Edwards, 1840 is monotypic contains the only species A. typus (Yule and Sen 2004). This species primarily occurs in the coastal ecosystem's fresh water and low salinity zone (Bruce 1983).

In India, most of the reports and records on parasitic isopods are concentrated around the south-east coast of India (Ravichandran et al. 2019). There are reports on the isopods parasites from the northern part of the east coast of India (NPECl), mainly from the state of Odisha and West Bengal (Chliton 1924; Seth et al. 2014; Dev Roy et al. 2015; Behera et al. 2016; Ray et al. 2016; Dev Roy and Rath 2017; Balakrishnan and Tudu 2020; Ray et al. 2020; Seth et al. 2020 a, b; Mohapatra et al. 2021; Seth et al. 2021), but still, a comprehensive report is lacking (Seth et al. 2020 a, b; 2021). Further, on the prevalence of these isopods on the host fish species, there is hardly any report from the NPECI. Therefore, this study was carried out to know the infection and prevalence of these isopods along the NPECl. 


\section{Materials And Methods}

During the study period (August 2010-January 2015), a routine observation (at the rate of 3-5 days per month/seasons) of the marine fishes from different selected fish landing stations of the NPECI viz. West Bengal (Digha, Shankarpur, Junput, Hijli-Dariapur, Kakdwip-Namkhana, and Sagar Island) and Odisha (Talsari, Chandipur, Dhamra, Paradip, Puri, Chilika, and Gopalpur) were conducted. Fishes and isopod were collected from fish landing centers where trawl net and gill net generally operated; some samples were also collected from shore seine nets. Fishes were checked carefully for ectoparasitic infection on their body surface, fins, gill, and buccal cavity. After photography, isopods were removed from their attachment sites with the help of fine forceps and placed into $70 \%$ ethanol. The isopods were examined using Leica-EZ4 microscope. Isopods were identified according to Trilles (1975 and 1979), Bowman and Tareen (1983), Bruce (1887), Rameshkumar et al. (2011) and (2012), and Trilles et al. (2013). The prevalence was calculated according to Margolis et al. (1982). Host species identification was based on Fischer and Bianchi (1984), Talwar and Kacker (1984), Froese and Pauly (2020). Specimens were deposited and registered in the Marine Aquarium and Regional Center (MARC), Zoological Survey of India, Digha. The specimens of A. typus was deposited and registered in Estuarine Biology Regional Centre, Zoological Survey of India, Gopalpur-on-Sea, Odisha. The registered specimens along with their voucher number are presented in table 1.The seasonal impacts of the parasites on the host were also examined.

\section{Results}

During the study, 14 species of parasitic isopods were found (Figure 1); from those, 13 species belong to family Cymothoidae and 01 species to the family Aegidae. Out of theses 14 species, 03 species viz., Catoessa boscii, Cymothoa eremita and Nerocila loveni are first record to the NPECI. Few selected photographs of hosts and their parasites collected during the study period are presented in figure 2. A comprehensive list of the isopods species along with their host collected during the study period and earlier report form Indian water are presented in Table 2. During this study, it was observed that isopods parasitized 34 species of host fishes under 19 families. Number of host fish species examined and parasitized by isopods are presented in Figure3. Most of the isopod attached with host species mainly three regions: body surface, buccal cavity, and inside the gill membrane (Branchial parasite). Host family-wise infection by isopods is provided in figure 4. Member of the family Carangidae are more parasitized by the isopods followed by Clupeidae, Scomberidae, and Leiognathidae (Figure 4). The percentage of dominating isopods genus wise and species wise are provided in figures 4 and 5 respectively. The dominating genus was Nerocila (Figure 5), Nerocila phaeopleura and Catoessa boschii are the main dominant isopod in these areas (Figure 6). The seasonal variation of isopod infection is presented in figure7. The Isopod prevalence was high during October to February (Post monsoon season of the study areas) and very low during April to August (monsoon season of the study areas) (Figure7). The prevalence is provided in table3. Total prevalence was 12.21. The prevalence was highest on Alepes djedaba (34.95) and lowest on Lutjanus johnii (1.29).

\section{Discussion And Conclusion}

The parasitic isopods viz., Catoessa boscii, Cymothoa eremita, and Nerocila loveni were not recorded earlier from the NPECl; therefore, this is the first materials evidence of these parasites from these regions. Further, the host record of Alepes djedaba, Alepes kleinii, and Leiognathus blochii for the parasite Catoessa boschii; the host record of Sardinella longiceps, Lactarius lactarius, and Leiognathus blochii for the parasite Anilocra 
dimidiata; the host Carangoides malabariucus for the parasite Nerocila depressa, the host Equulites leuciscus for the parasite N. loveni, the host fish species Siganus javas, and Epinephelus coioides for the parasite $N$.

phaiopleura, the host fish species Alepes djedaba for the parasite N. poruvae, the host fish species Arius arius, and Terapon jarbua, Plotosus lineatus, Nibea maculate for the parasite $N$. serra, and the host fish species Nemipterus japonicus, and Priacanthus tayneus for the parasite $N$. sigani are the new host records for the northern part of east coast of India (Table2).

As these isopods are connected with many host species during the study period (Figure 3 and 4, Table 2 and 3), it indicates higher diversity of fishes in the NPECI. The Nerocila is the dominating genus during the study period (Figure 5 and 6), which shows the high adaptability of the species of the genus to a range of environmental conditions prevailing in these regions. The high prevalence of isopod on the host species Alepes djedaba (Table3) may be due to the higher host-specificity of parasitic isopods for this host species in these regions.

The Isopod prevalence was high during post-monsoon than monsoon (Figure7). It may occur due to the lesser salinity of the water in these sampling areas during the monsoon period compared to post-monsoon. During monsoon, lower salinity is due to higher rainfall and freshwater discharge through estuarine influence. During post-monsoon, salinity gradually increases, and this condition facilitates the isopods infestation. During this study, it is observed that most of the Nerocila species were ovigerous throughout the year, but the prevalence was high during post-monsoon; thus, optimum salinity may be the reason and is helping in larval development. In many free-living crustaceans, post-monsoon plays a vital role in their breeding, and climatic conditions affect the reproduction of Cymothoidae (Sudha and Anilkumar 1996; Syama et al. 2010; Leanarods and Trilles 2003).

In recent times, study on the infection and prevalence of parasitic isopods on commercial fishes were reported from Paranagipettai coast, India (Bharadhirajan, 2014), Malabar Coast, India (Aneesh et al. 2016; Rijin et al. 2017), Mirri, East Malaysia (Anand Kumar et al.2015, 2017), Atlantic menhaden (Rose et al.2020) and other parts of the globe as well. However, before the present report, no such comprehensive study based on the infection parasitic isopods on the commercial fishes of NPECI was reported. Therefore, the extension of this work on the infection pattern and other aspects of the host-parasite relationship in these regions will provide more insight into the isopods biology.

\section{Declarations}

\section{Acknowledgement}

We would like to express our thankfulness to Director, Zoological Survey of India for providing necessary facilities to work.

\section{Conflict of interest statements}

Authors declare that they have no conflict of interest.

\section{Research involving human participants and/or animals}

Since the animals are not under schedule lists/protected categories, so ethical clearance is not applicable. 


\section{Informed Consent}

Not applicable

\section{Funding}

Not applicable

\section{References}

Anand Kumar A, Rameshkumar G, Ravichandran S, Priya ER, Nagarajan R, Alex Goh (2015) Occurrence of cymothoid isopod from Miri, East Malaysian marine fishes. J Parasit Dis 39(2):206-210.

Anand Kumar A, Rameshkumar G, Ravichandran , Nagarajan R, Prabakaran K, Ramesh M (2017) Distribution of isopod parasites in commercially important marine fishes of the Miri coast, East Malaysia. J Parasit Dis 41: 55-61. https://doi.org/10.1007/s12639-016-0749-6

Al-Zubaidy AB, Mhaisen FT (2014) The first record of four isopods from some red sea fishes, Yemeni coastal waters. Bull Iraq Nat Hist Mus

$13(1): 35-51$

Aneesh PT, Helna AK, Sudha K (2016) Branchial cymothoids infesting the marine food fishes of Malabar coast. J Parasit Dis 40 (4):1270-1277.

https://doi.org/10.1007/s12639-015-0666-0

Aneesh PT, Helna AK, Valarmathi K, Chandra K, Mitra S (2017) Redescription of Nerocila exocoeti Pillai, 1954 (Crustacea: Isopoda:

Cymothoidae) parasitic on beloniform (Exocoetidae and Hemiramphidae)

hosts with Nerocila madrasensis Ramakrishna \& Ramaniah, 1978 placed into synonymy. Zootaxa 4365 (3): 385-394.

Aneesh PT, Sudha K, Arshad K, Anil kumar G, Trilles JP (2013) Seasonal fluctuation of the prevalence of Cymothoids representing the genus Nerocila (Crustacea, Isopoda), parasitizing commercially exploited marine fishes from the Malaber coast, India. Acta Parasitol 58(1). 80-90.

Bal DV, Joshi UN (1959) Some new isopod parasites on fishes. J Bombay Nat Hist Soc 56:563-569.

Balakrishnan S, Tudu PC (2020) New host records for Nerocila depressa Milne Edwards, 1840 (Crustacea, Isopoda, Cymothoidae) from Digha coast, Bay of Bengal, India. Indian J Geo-Mar Sci 49(4):698702. http://nopr.niscair.res.in/handle/123456789/54638

Barnard KH (1936) Isopods collected by the R.I.M.S. "Investigator". Records of the Indian Museum, Calcutta, 38:147-191.

Behera, PR, Ghosh S, Pattnaik P, Rao MV (2016) Maiden occurrence of the isopod, Norileca indica (H. Milne Edwards, 1840) in pelagic and demersal finfishes of Visakhapatnam waters along 
north-west Bay of Bengal. Indian J Geo-Mar Sci 45(7):856-

862. http://nopr.niscair.res.in/handle/123456789/35129

Bharadhirajan P, Murugan S, Sakthivel A Selvakumar P (2014) Isopods parasites infection on commercial fishes of Parangipettai waters, southeast coast of India. Asian Pac J Trop Dis 4 (Suppl 1): S268-

S272. https://doi.org/10.1016/S2222-1808(14)60453-9

Bowman TE, Tareen IU (1983) Cymothoidae from fishes of Kuwait (Arabian Gulf) (Crustacea: Isopoda). Smit Contrib Zool 382:1-30.

Bruce NL (1983) Aegidae (Isopoda: Crustacea) from Australia with descriptions of three new species. J Nat Hist 17:757-788. https://doi.org/10.1080/00222938300770591

Bruce NL (1987) Australian species of Nerocila Leach, 1818, and Creniola n. gen. (Isopoda: Cymothoidae), crustacean parasites of marine Fishes. Rec Aus Mus 39:355-412.

Bruce NL, Harrison-Nelson EB (1988) New records of fish parasitic marine Isopod Crustaceans (Cymothoidae, subfamily Anilocrinae) from the Indo-West Pacific. P Biol Soc Wash 101: 585-602.

Chidambaram K, Menon DM (1945) The isopod parasite Nerocila sundaica, on West Coast food fishes. Curr Sci 14 (11): $308 \mathrm{pp}$

Chilton C (1924) Fauna of the Chilka Lake. Tanaidacea \& Isopoda. Memoirs of the Indian Museum 5: 875-895.

Dev Roy MK (2012) A systematic list of isopod fauna hitherto known from India. Zoological Survey of India, Crustacea Section, 1-20.

Dev Roy MK, Mitra S (2013) New host record for Nerocila sigani (Isopoda:Cymothoidae) from Odisha coast, India. Curr Sci 104 (9): 1134-1135.

Dev Roy MK, Mitra S, Gokul A (2012) On a new host record of Nerocila poruvae (Crustacea: Isopoda: Cymothoidae) From West Bengal. J. Environ. \& Sociobiol 9(1):105-107.

Dev Roy MK, Rath, S (2017) An inventory of crustacean fauna from Odisha coast, India. J Environ Sociobiol 14(1):49-112.

Dev Roy MK, Rath, S, Mitra S, Mishra SS (2015) Rabbit fish Siganus canaliculatus-a new host record for isopod parasite Nerocial arres Bowman and Tareen, 1983. J Bombay Nat Hist Soc 112(3):177-178. http://dx.doi.org/10.17087/jbnhs\%2F2015\%2Fv112i3\%2F114432 .

Fischer W,Bianchi G (eds) (1984) FAO Species Identification sheets for Fishery purpose, Western Indian Ocean; (Fishing area 51), (Prepared and printed with the support of the Danish International Development Agency (DANIDA). Rome, Food and Agricultural Organization of the United Nations) vols 1-6: pag. var.

Froese R, Pauly D (2021) FishBase. World Wide Web electronic publication. Available from: http://www.Fishbase.org, Version (06/2021). Accessed 27 July 2021. 
Ghatak SS (1998) Crustacea: Isopod. State fauna Series 3: Fauna of West Bengal, Part 10, Zool Surv India 315327.

Jayadev Babu S, Sanjeeva Raj PJ (1984) Isopod parasites of fish of Pulicat Lake. Proceedings Symposium of Coastal Aquaculture (Fin Fish) 3: 818-823.

Jemi JN, Hatha AAM, Radhakrishnan CK (2020) Seasonal variation of the prevalence of cymothoid isopod Norileca indica (Crustacea, Isopoda), parasitizing on the host

fish Rastrelliger kanagurta collected from the Southwest coast of India. J Parasit

Dis 44: 314-318. https://doi.org/10.1007/s12639-020-01208-6 .

Leonardos I, Trilles JP (2003) Host-parasite relationships: occurrence and effect of the parasitic isopod Mothocya epimerica on sand smelt Atherina boyeri in the Mesolongand Etolikon Lagoons (W. Greece). Dis aquat Org 54: 243-251.

Margolis L, Esch GW, Holmes JC, Kuris AM, Schad GA (1982) The use of ecological terms in parasitology (report of an ad hoc committee of the American Society of Parasitologists). J Parasitol 68: 131-133.

Mitra S, Dev Roy MK (2011) On a new host record of Alitropus typus (Crustacea:Isopoda: Aegidae) and a new record from a freshwater river system of West Bengal. J Environnt Sociobiol 8(2):269- 271.

Mohapatra SK, Mohanty SR, Behera RK, Seth JK, Mohapatra A (2021) First record of Mothocya renardi and Mothocya collettei (Isopoda: Cymothoidae) from northern part of East Coast of India and new host record of Mothocya collettei. J Parasit Dis 45:651-654. https://doi.org/10.1007/s12639-021-01348-3

Nair GA, Nair NB (1983) Effect of infestation with the isopod, Alitropus typus M. Edwards (Crustacea: Flabellifera: Aegidae) on the haematological parameters of the host fish Channa striatus (Bloch). Aquac 30:1119.

Neeraja T, Tripathi G, Shameem U (2014) Occurrence of the isopod, Nerocila indiaca (Isopoda: Cymothoidae) on bigeye scad, Selar crumenophthalmus (Bloch) off Mumbai coast, India. Indian J Fish 61(1): 49-56.

Parimala S (1984) Nerocila pigmentata Bal \& Joshi (Isopoda: Cymothoidae) parasitic on Nematalosa nasus (Bloch). J Mar Biol Ass India 21(for 1979):180-181.

Parveen Rattan, Parulekar AH (1998) Diseases and parasites of laboratory reared and wild population of banded pearl spot Etroplus suratensis (Cichlidae) in Goa. Indian J Mar Sci 27(3-4):407-410.

Pillai NK (1954) A preliminary note on the Tanaidacea and Isopoda of Travancore. Bulletin of the Central Research Institute, University of Travancore (C) 3, no. 1, 1-21.

Raja K, Vijayakumar R, Karthikeyan V, Saravanakumar A, Sindhuja K, Gopalakrishnan A (2014) Occurrence of isopod Nerocila phaiopleura infestation on Whitefin wolf-herring (Chirocentrus nudus) from Southeast coast of India. J Parasit Dis 38(2):205-207.

Rajkumar M, Perumal P (2004) Effect of Isopod parasite, Nerocila pheaopleura on Stolephorus commersonii Fish from Parangipettai coastal waters (south east coast of India). Appl Fish Aqua IV (2):17-23. 
Rajkumar M, Perumal P, Trilles JP (2006) On the occurrence of a double parasitism (copepod and isopod) on the anchovy fish in India. J Environ Biol 27(3): 613-614.

Rajkumar M, Thavasi R, Trilles JP, Perumal P (2008) Vibriosis and Parasitic Isopod Infections in the Black Fin Sea Catfish, Arius jella. Advances in Aquatic Ecology, 2, Chapter 13:102-109.

Ramakrishna G, Ramaniah V (1978) A new cymothoid of the genus Nerocila from Madras. Bull Zool Sur Ind 1: 177-180.

Rameshkumar G, Ramesh M, Ravichandranm S, Trillers, JP, Shobana C (2015b) Nerocila sundaica (Isopoda, Cymothoidae) parasitizing Otolithes ruber from Nagapattinam, Southeast coast of India J Parasit Dis 39(4):78992.

Rameshkumar G, Ramesh, M, Ravichandran, S, Trillers, JP, Subbiah S (2015a) New record of Norileca indica from the west coast of India. J Parasit Dis 39(4):712-5.

Rameshkumar G, Ravichandran S (2010) New Host Record, Rastrelliger kanagurta, for Nerocila phaeopleura Parasites (Crustacea, Isopoda, Cymothoidae).Middle-East J Scientific Res 5 (1): 54-56.

Rameshkumar G, Ravichandran S (2013) Effect of the parasitic isopod, Catoessa boscii (Isopoda, Cymothoidae) a buccal cavity parasite of the marine fish, Carangoides malabaricus. Asian Pac J Trop Biomed 3(2):118-122.

Rameshkumar G, Ravichandran S, and Ramesh M (2016) Distribution of Isopod parasitesin Carangid fishes from Parangipettai, Southeast coast of India. J Parasit Dis 40(1):124-8.

Rameshkumar G, Ravichandran S, Sivasubramanian K (2013a) Invasion of parasitic isopod in marine fishes. J Coast Life Med1(2): 88-94.

Rameshkumar G, Ravichandran S, Sivasubramanian K, Trilles JP (2013b) New occurrence of parasitic isopods from Indian fishes. J Parasit Dis 37(1) 42-46.

Rameshkumar G, Ravichandran S, Trilles JP (2011) Cymothoidae (Crustacea, Isopoda) from Indian fishes. Acta Parasitol 56:(78-91). DOI: 10.2478/s11686-011-0002-5.

Ravichandran S, Ranjith Singh AJA, Veerappan N (2001) Parasite induced vibriosis in Chirocentrus dorab off Parangipettai coastal waters. Curr Sci 80:101-102.

Ravichandran S, Vigneshwaran P, Rameshkumar G (2019) A taxonomic review of the fish parasitic isopod family Cymothoidae Leach, 1818 (Crustacea: Isopoda: Cymothooidea) of India. Zootaxa 4622 (1):1099. https://doi.org/10.11646/zootaxa.4622.1.1.

Ray D, Mitra S, Balakrishna S, Mohapatra A (2020) New host records of Nerocila poruvae (Isopoda: Cymothoidae) from the Northern part of the east coast of India and first report of a fish - Ablennes hians (Valenciennes, 1846) from West Bengal coast. Indian J Geo-Mar Sci 49 (08):1447-

1451. http://nopr.niscair.res.in/handle/123456789/55302 
Ray D, Mitra S, Mohapatra A (2016) First report of parasitic isopod

Norileca indica Milne-Edwards, 1840 from Northern part of East

Coast of India. Int J Exp Res Rev 4:19-25

Rijin K, Sudha K, Vineesh PJ, Anilkumar G (2017) Seasonal Variation in the Occurrence of Parasitic Isopods and Copepods (Crustacea) Infecting the Clupeidaen Fishes of Malabar Coast, India. Turk J Fish \& Aqua. Sci 19(3), 241-249.http://doi.org/10.4194/1303-2712-v19_3_07.

Rose DP, Calhoun DM, Johnson PTJ (2020) Infection prevalence and pathology of the cymothoid parasite Olencira praegustator in Atlantic menhaden. Invertebr Biol 00:e12300. https://doi.org/10.1111/ivb.12300.

Saravanakumar A, Balasubramanian T, Raja K, Trilles JP (2012) A massive infestation of sea snakes by cymothoid isopods. Parasitol Res 110: 2529-2531.

Seepana R, Nigam NK, Musaliyarakam N, Chandrakasan S (2021) Occurrence of ectoparasitic isopod Norileca indica (H. Milne Edwards, 1840) on bigeye scad Selar crumenophthalmus (Bloch, 1793) from Great Nicobar Island, India. J Parasit Dis 45(2):306-312.

Seth JK, Behera AK, Mohanty SR, Mohapatra A. (2020a) Extension of host range for Anilocra dimidiata, Nerocila sigani and first record of Nerocila depressa (Isopod: Cymothiod) from Odisha coast, India. Indian J Geo-Mar Sci 49(8):1498-1500.

Seth JK, Chakraborty S, Roy S, Mohapatra A (2020b) New host record of Joryma malabaricus, Joryma hilsae and first record of Joryma sawayah (Isopoda: Cymothoidae) from Odisha coast, India. Indian J Geo-Mar Sci 49(8):1501-1504.

Seth JK, Mohapatra SK, Mohanty SR, Behera RK, Mohapatra A (2021) Confirmation on the occurrence of Cymothoa indica, and first record of Norileca indica, with a note on new host records of Nerocila arres, and Nerocila depressa (Isopoda: Cymothoidae) from Odisha coast, India. J Parasit Dis.

https://doi.org/10.1007/s12639-021-01382-1

Seth JK, Sahoo S, Mitra S (2014) First record of isopod parasite, Nerocila phaeopleura on the host fish Rastrelliger kanagurta collected from Bay of Bengal, Odisha Coast, India. Int J Curr Res 6(4): 6092-6093.

Sivasubramanian K., Ravichandran S., Rameshkumar G, Allayie SA (2011) Infection of Exocoetus volitans (Linnaeus, 1758) a new host of Nerocila exocoeti (Crustacea,Isopoda, Cymothoidae). Sci Parasitol 2(2): 99-101.

Smit NJ, Bruce NL, Hadfield KA (2014) Global diversity of fish parasitic isopod crustaceans of the family Cymothoidae. International Journal for Parasitology: Parasites and Wildlife 3: 188-197.

Sudha K, Anilkumar G (1996) Seasonal growth and reproduction in a highly fecund brachyuran crab Metopograpsus messor (Forskal) (Grapsidae). Hydrobiologia. 319:15-21.

Syama VP, Supriya NT, Sudha K, Anil kumar G (2010) Seasonal growth and reproduction in two brachyuran species inhabiting diverse ecosystems. In: Gupta Verma VKAK, Singh JD (eds.) Perspectives in Animal Ecology and Reproduction. Daya Publications, Vol. VI, New Delhi, pp. 275-289. 
Talwar P K \& Kacker P K (1984) Commercial Sea Fishes of India,

Zool Surv India,1-997.

Trilles JP (1975) Les Cymothoidae (Isopoda, Flabellifera) des cotes francaises. II. Les Anilocridae Schioedte et Meinert, 1881. Genres Anilocra Leach, 1818, et Nerocila Leach, 1818. Bull Mus natn Hist nat, Paris 3e serie 290 (Zoologie 200):347-378.

Trilles JP (1979) Les Cymothoidae (Isopoda, Flabellifera; Parasites de Poissons) du Rijksmuseum van Natuurlijke Historie de Leiden: II. Afrique, Amérique et régions Indo-Ouest-Pacifiques Zool meded, 54: $245-275$.

Trilles JP, Rameshkumar G, Ravichandran S (2013) Nerocila species (Crustacea, Isopod, Cymothoidae) from Indian marine fishes. Parasitol Res, 112: 1273-1286. DOI 10.1007/s00436-012-3263-5

Trilles JP, Ravichandran S, Rameshkumar G (2012) Catoessa boscii (Crustacea,Isopoda, Cymothoidae) parasitic on Carangoides malabaricus (Pisces, Carangidae)from India. Taxonomy and host-parasite relationships. Acta parasitol 57(2):179-189. DOI: 10. 2478/s11686-012-0020-y.

Veerapan N, Ravichandran S (2000) Isopod parasites from marine fishes of Parangipettai coast. Centre of Advanced Study in Marine Biology, Annamalai University, Parangipettai, 24 pp.

Yule CM, Sen YH (2004) Freshwater Invertebrates of the Malaysian

Region. Academy of Sciences Malaysia, Kualalumpur.PP:298-

306. https://research.usc.edu.au/discovery/fulldisplay/alma99450876802621/61USC_INST:ResearchRepository

\section{Tables}

Table 1: Specimens along with their voucher numbers 


\begin{tabular}{ll} 
Name of the species & Voucher number \\
\hline Anilocra dimidata & MARC/ZSI/A3962 \\
\hline Catoessa boschii & MARC/ZSI/A3963 \\
\hline Cymothoa eremita & MARC/ZSI/A3964 \\
\hline Nerocila depressa & MARC/ZSI/A3965 \\
\hline Nerocila exocoeti & MARC/ZSI/A3659, MARC/ZSI/A3966 \\
\hline Nerocila phaeopleura & MARC/ZSI/A3969 \\
\hline Nerocila poruvae & MARC/ZSI/A3660, MARC/ZSI/A3970 \\
\hline Nerocila longispina & MARC/ZSI/A3967 \\
\hline Nerocila loveni & MARC/ZSI/A3661, MARC/ZSI/A3968 \\
\hline Nerocila serra & MARC/ZSI/A3971 \\
\hline Nerocila sigani & MARC/ZSI/A3972 \\
\hline Nerocila sundaica & MARC/ZSI/A3973 \\
\hline Norileca indica & MARC/ZSI/A3662, MARC/ZSI/A3974 \\
\hline Alitropus typus & EBRC/ZSI/ Cr-13291 \\
\hline
\end{tabular}

Table 2: A comprehensive host-parasite list and localities with references to 13 isopod species of family Cymothoidae and one species of the family Aegidae found along the northern part of the east coast of India and other regions of India ( Note: * indicates new host record to the northern part of the east coast of India) 
Isopod

species

Host species

\section{Buccal Parasites (Family:Cymothoidae)}

Catoessa Carangoides malabaricus

boschii
Localities

Parangipettai Coast and South-east coast
Trilleset al. 2012, Rameshkumaret al. 2016, Ravichandran et al.2019
Alepes djedaba*, Alepes kleinii*,Leiognathus

blochii*, Carangoides malabaricus

Cymothoa Eleutheronema tetradactylum, eremita
Lutjanus johnii, Lutjanus argentimaculatus,

Mystus gulio, Nemapteryx nenga,

Nematalosa nasus, Chanos chanos, Platycephalus indicus.

Etroplus suratensis
Goa Coast

Present study

Pulicat Lake

Jayadev Babu and Sanjeeva Raj, 1984.

References 


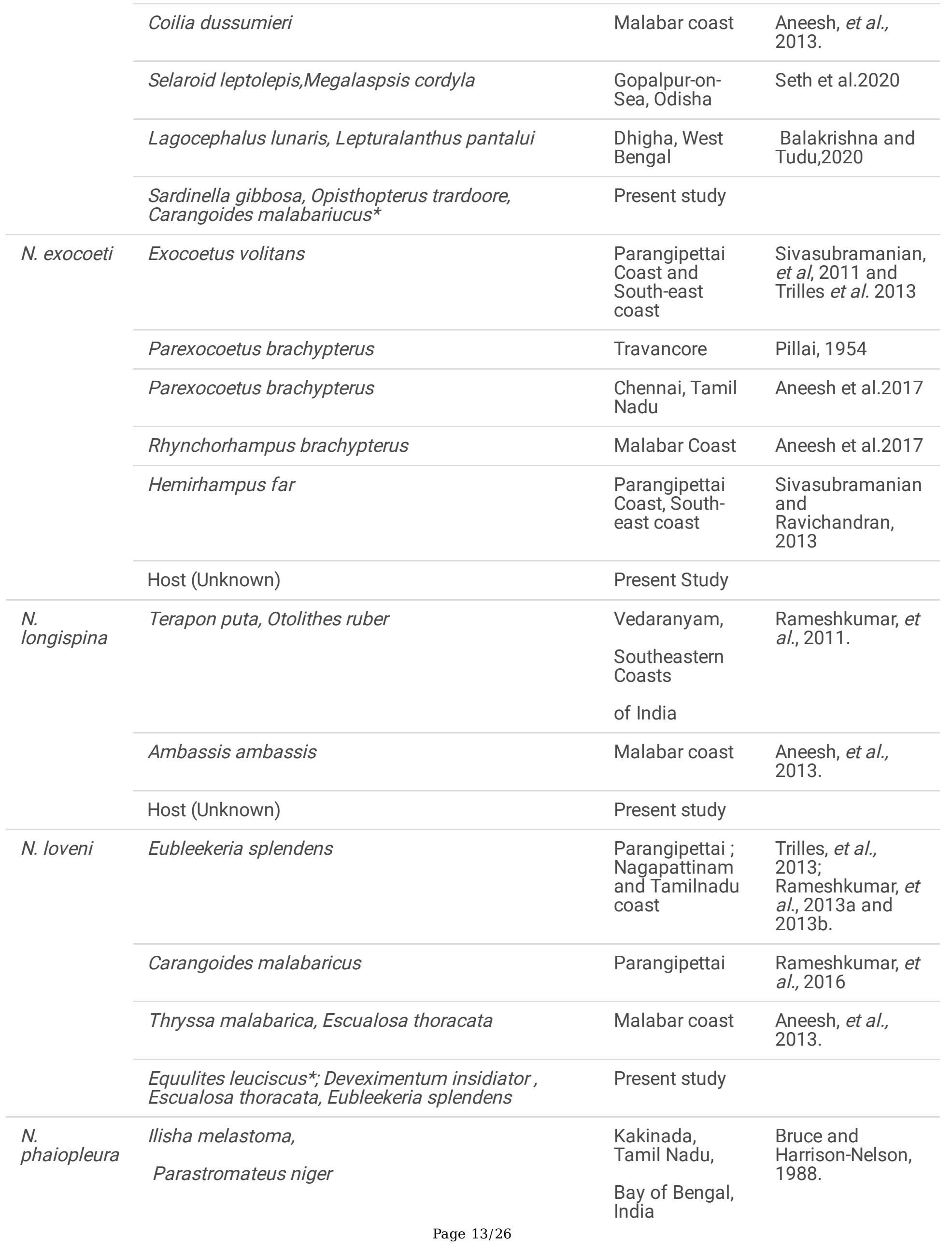




\begin{tabular}{|c|c|c|}
\hline $\begin{array}{l}\text { Chirocentrus dorab, Sardinella } \\
\text { longiceps, S. sindensis, S. brachysoma }\end{array}$ & $\begin{array}{l}\text { Parangipettai } \\
\text { Coast }\end{array}$ & $\begin{array}{l}\text { Veerapan and } \\
\text { Ravichandran, } \\
2000 \text {. }\end{array}$ \\
\hline \multicolumn{3}{|l|}{ Dussumieria acuta, Thryssa dussumieri, } \\
\hline \multicolumn{3}{|l|}{ T. mystax, Scomberomorus guttatus } \\
\hline Chirocentrus dorab & $\begin{array}{l}\text { Parangipettai } \\
\text { Coast }\end{array}$ & $\begin{array}{l}\text { Ravichandran, et } \\
\text { al., } 2001 .\end{array}$ \\
\hline Stolephorus commersonnii & $\begin{array}{l}\text { Parangipettai } \\
\text { Coast }\end{array}$ & $\begin{array}{l}\text { Rajkumar and } \\
\text { Perumal, 2004; } \\
\text { Rajkumar, et al., } \\
2006 .\end{array}$ \\
\hline Arius jella & $\begin{array}{l}\text { Parangipettai } \\
\text { Coast }\end{array}$ & $\begin{array}{l}\text { Rajkumar, et al., } \\
2008 .\end{array}$ \\
\hline Istiophorus platypterus & Bay of Bengal & Barnard, 1936. \\
\hline Istiophorus platypterus & Chennai & Ramakrishna \\
\hline & & $\begin{array}{l}\text { and Venkata } \\
\text { Ramaniah,1978. }\end{array}$ \\
\hline \multirow[t]{3}{*}{ Rastrelliger kanagurta } & Parangipettai, & Rameshkumar \\
\hline & $\begin{array}{l}\text { Southeast } \\
\text { Coast }\end{array}$ & $\begin{array}{l}\text { and } \\
\text { Ravichandran, } \\
2010 .\end{array}$ \\
\hline & $\begin{array}{l}\text { Goapalpur-on- } \\
\text { Sea, Odisha } \\
\text { coast }\end{array}$ & Seth, et al., 2014 \\
\hline $\begin{array}{l}\text { Carangoides malabaricus, Chirocentrus dorab } \\
\text { Dussumieria acuta, Gazza minuta, Eubleekeria } \\
\text { splendens, Rastrelliger kanagurta, Sardinella } \\
\text { gibbosa, S. longiceps, Scleroides leptolepis, } \\
\text { Sphyraena jello, Tenualosa ilisha, Thryssa mystax. }\end{array}$ & $\begin{array}{l}\text { Tamilnadu } \\
\text { coast }\end{array}$ & Trilles, et al., 2013 \\
\hline Istiophorus platypterus & $\begin{array}{l}\text { South } 24 \\
\text { Parganas, West } \\
\text { Bengal }\end{array}$ & Ghatak, 1998 \\
\hline Liza parsia, Thryssa dussumieri, Sardinella albella & Parangipettai & $\begin{array}{l}\text { Bharadhrirajan, et } \\
\text { al., } 2014 \text {. }\end{array}$ \\
\hline $\begin{array}{l}\text { Thryssa mystax, Thryssa setirostris, Thryssa } \\
\text { malabarica, Opisthopterus tardoore }\end{array}$ & Malabar coast & $\begin{array}{l}\text { Aneesh, et al., } \\
2013\end{array}$ \\
\hline Sardinella gibbosa & $\begin{array}{l}\text { Tamilnadu } \\
\text { coast }\end{array}$ & $\begin{array}{l}\text { Rameshkumar, et } \\
\text { al., 2013a. }\end{array}$ \\
\hline Chirocentrus nudus & $\begin{array}{l}\text { Cuddalore, } \\
\text { Tamilnadu }\end{array}$ & Raja, et al., 2014 \\
\hline $\begin{array}{l}\text { Siganus javas*, Sardinella gibbosa, Sardinella } \\
\text { longiceps, Dusumeria acuta, Opisthopterus tardoore, } \\
\text { Carangoides malabaricus, Epinephelus coioides*, } \\
\text { Thryssa dusummeri, Scleroides leptolepis, }\end{array}$ & Present study & \\
\hline
\end{tabular}


Rastreliger kanagurta, Parastromateus niger,

Leiognathus splendens

N. poruvae Trichurus leturus; Thryssa mystax

Vedaranyam

Rameshkumar, et

Coast, al., 2011.

Southeastern

Coast

Setipinna tenuifilis

Bakkhali and

Digha

Dev Roy, et al.,

Siganus canaliculatus

Paradip, Odisha Ray et al. 2020

Setipinna taty, Ablennes hians, Rhynchirhampus gorgii, Pampus argentus

Digha, West

Bengal

Ray et al. 2020

Siganus canaliculatus, Alepes djedaba*, Rhynchirhampus gorgii, Setipinna taty

Present study

N. serra Hexanematichthys sagor

Off Devi River,

Barnard, 1936.

Odisha Coast,

Vizagapatam,

Canjam Coast

(Odisha)

On several species of shoal fishes

Travancore

Pillai, 1954.

Arius maculatus

Nagappatinam

Trilles, et al., 2013

Host (Unknown)

West Bengal,

Ghatak, 1998.

Odisha,

Andhrapradesh

Enhydrina schistose (Sea snake)

Parangipettai

Saravanakumar, coast et al., 2012.

Arius arius*; Arius maculatus, Terapon jarbua*, Plotosus lineatus*, Nibea maculate*

Present study

N. sigani Parastromateus niger

Formio niger

Bruce and

Parastromateus

Harrison-Nelson, niger

Siganus oramin

Parangipettai

and 1988.

Nagapattinam

Trilles, et al., 2013 and

Rameshkumar, et al.. 2013b.

Terapon threps

Paradip, Odisha

Dev Roy and

Mitra, 2013.

Lutjanus lutjanus

Gopalpur-on-

Sea, Odisha

Seth et al. 2020

Present study

Lutjanus lutjanus, Nemipterus japonicas*,

Priacanthus tayneus*, Parastromateus niger. 
(Sacraments

mouth),

Ganjam Coast

Otolithes ruber, Terapon jarbua, Thryssa mystax,

West Coast of India

Epinephelus quoyanus, Ilisha melastoma, Sardinella fimbriata

Chidambaram

Estuarine fishes

West Bengal, odisha

and Devidas

Menon, 1945.

Carangoides malabaricus Ilisha
melastomaOtolithoides ruber, Scleroides leptolepis,
Terapon puta, Opisthopterus tardoore

\section{Parangipettai}

Coast and

South-east

coast.

Ghatak, 1998

Tamilnadu

Coast

Trilles, et al., 2013;

Rameshkumar, et al., 2016;

Rameshkumar, et

al,. 2013b

Otolithes ruber

Nagapattinam,

Southeast

Rameshkumar, et coast al., 2015 b.

Norileca

indica
Terapon jarbua

Rastrelliger kanagurta
Present study

Parangipettai and Cochin

Rameshkumar, et al., 2013a \& 2013b and 2015

a.

Aneesh et al. (2016)

Malabar coast

Behera et al. (2016)

Visakhapatnam

Shankarpur,

West Bengal

Ray et al. (2016)

Cochin coast

Jemi et al. (2020)

Atule mate

Gopalpur-on-

Sea

Selar crumenophthalmus

Off Mumbai

coast

Seth et al.2021

Neeraja, et al., 2014

Selar crumenophthalmus

Great Nicobar

Island

Deveximentum insidiator, Nemipterus randalli

Visakhapatnam

Present study
Behera et al. (2016) 
Body Surface parasites (Family:Aegidae)

\begin{tabular}{llll}
$\begin{array}{l}\text { Alitropus } \\
\text { typus }\end{array}$ & Channa striata & Tamil Nadu & $\begin{array}{l}\text { Nair and Nair } \\
1983\end{array}$ \\
\cline { 2 - 3 } & Oreochromis mossambicus & Tamil Nadu & $\begin{array}{l}\text { Rameshkumar } \\
\text { and } \\
\text { Ravichandran } \\
2010\end{array}$ \\
\hline Badis badis & & $\begin{array}{l}\text { Mitra and Deb } \\
\text { Roy 2011 }\end{array}$ \\
\hline Etroplus suratensis, Oreochromis mosambicus & Damoder river & \\
Present Study &
\end{tabular}

Table 3: Prevalence of Isopod during the study period 


\begin{tabular}{|c|c|c|c|c|}
\hline Host Species & Family & $\begin{array}{l}\text { Examined host } \\
\text { species }\end{array}$ & $\begin{array}{l}\text { Infected host } \\
\text { species }\end{array}$ & Prevalence \\
\hline Sardinella gibbosa & Clupeidae & 125 & 38 & 30.4 \\
\hline Sardinella longiceps & Clupeidae & 119 & 35 & 29.41 \\
\hline Dussumeria acuta & Clupeidae & 34 & 4 & 11.76 \\
\hline Escualosa thoracata & Clupeidae & 78 & 9 & 11.53 \\
\hline Thryssa dusummeri & Engraulidae & 83 & 7 & 8.43 \\
\hline Setipinna tati & Engraulidae & 78 & 4 & 5.12 \\
\hline Opisthopterus tardoore & Pristrigasteridae & 121 & 16 & 13.22 \\
\hline Alepes djedaba & Carangidae & 148 & 51 & 34.45 \\
\hline Alepes kleinni & Carangidae & 143 & 16 & 11.18 \\
\hline $\begin{array}{l}\text { Carangoides } \\
\text { malabariucus }\end{array}$ & Carangidae & 104 & 20 & 19.23 \\
\hline Parastromateus niger & Carangidae & 128 & 6 & 4.68 \\
\hline Scleroides leptolepis & Carangidae & 79 & 6 & 7.59 \\
\hline Rastrelliger kanagurta & Scomberidae & 124 & 28 & 22.58 \\
\hline $\begin{array}{l}\text { Rhynchorhamphus } \\
\text { georgii }\end{array}$ & Hemirhamphidae & 17 & 1 & 5.88 \\
\hline Ablennes hians & Belonidae & 9 & 1 & 11.11 \\
\hline Lactarius lactarius & Lacteridae & 25 & 1 & 4 \\
\hline Eubleekeria splendens & Leiogonathidae & 61 & 7 & 11.47 \\
\hline Leiognathus blochii & Leiogonathidae & 56 & 5 & 8.92 \\
\hline Equulites lecuciscus & Leiogonathidae & 12 & 1 & 8.33 \\
\hline Secutor insidiator & Leiogonathidae & 124 & 12 & 9.67 \\
\hline Plotosus lineatus & Plotosidae & 62 & 7 & 11.29 \\
\hline Nibea maculata & Sciaenidae & 89 & 6 & 6.74 \\
\hline Siganus canaliculatus & Siganidae & 65 & 2 & 3.07 \\
\hline Siganus javus & Siganidae & 32 & 1 & 3.12 \\
\hline Lutjanus johnii & Lutjanidae & 77 & 1 & 1.29 \\
\hline Lutjanus lutjanus & Lutjanidae & 54 & 1 & 1.85 \\
\hline Terapon jarbua & Terapontidae & 102 & 8 & 7.84 \\
\hline Pryacanthus tayneus & Pryacanthidae & 105 & 2 & 1.9 \\
\hline \multirow[t]{2}{*}{ Nemipterus japonicus } & Nemipteridae & 125 & 11 & 8.8 \\
\hline & & Page $18 / 26$ & & \\
\hline
\end{tabular}




\begin{tabular}{|c|c|c|c|c|}
\hline Arius arius & Ariidae & 98 & 9 & 9.18 \\
\hline Arius maculatus & Ariidae & 37 & 2 & 5.4 \\
\hline Epinephelus coioides & Serranidae & 49 & 2 & 2.53 \\
\hline Etroplus suratensis & Cichlidae & 69 & 5 & 7.24 \\
\hline Tilapia mosambicus & Cichlidae & 36 & 1 & 2.77 \\
\hline Total & & 2668 & 326 & 12.21 \\
\hline
\end{tabular}

\section{Figures}




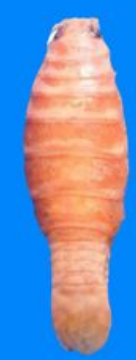

Anilocra dimidiata

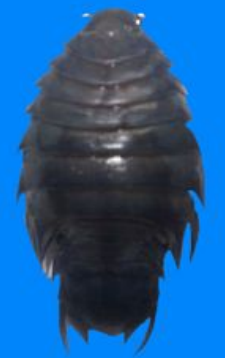

Nerocila exocoeti

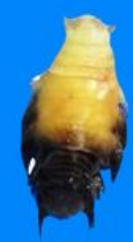

Nerocila poruvae

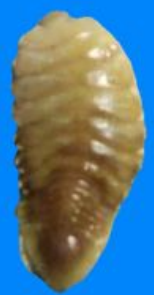

Norileca indica

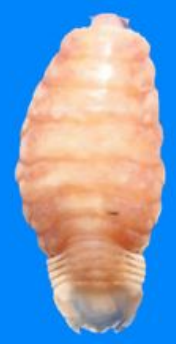

Catoessa boscii

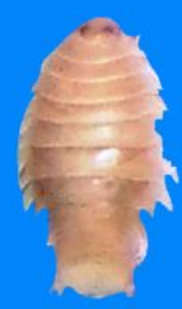

Nerocila longispina

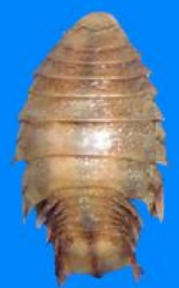

Nerocila serra

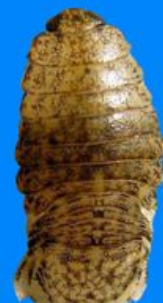

Alitropus typus

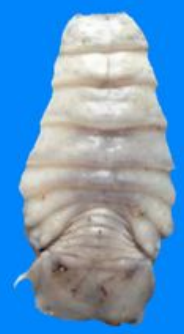

Cymothoa eremita

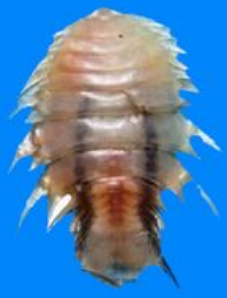

Nerocila loveni

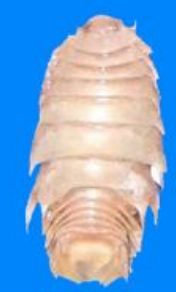

Nerocila sigani

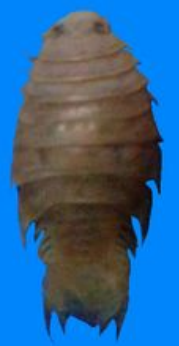

Nerocila depressa

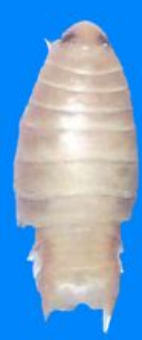

Nerocila phaiopleura

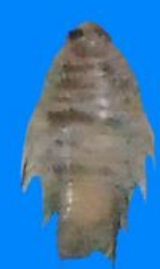

Nerocila sundaica

\section{Figure 1}

Parasitic isopods collected during the study 


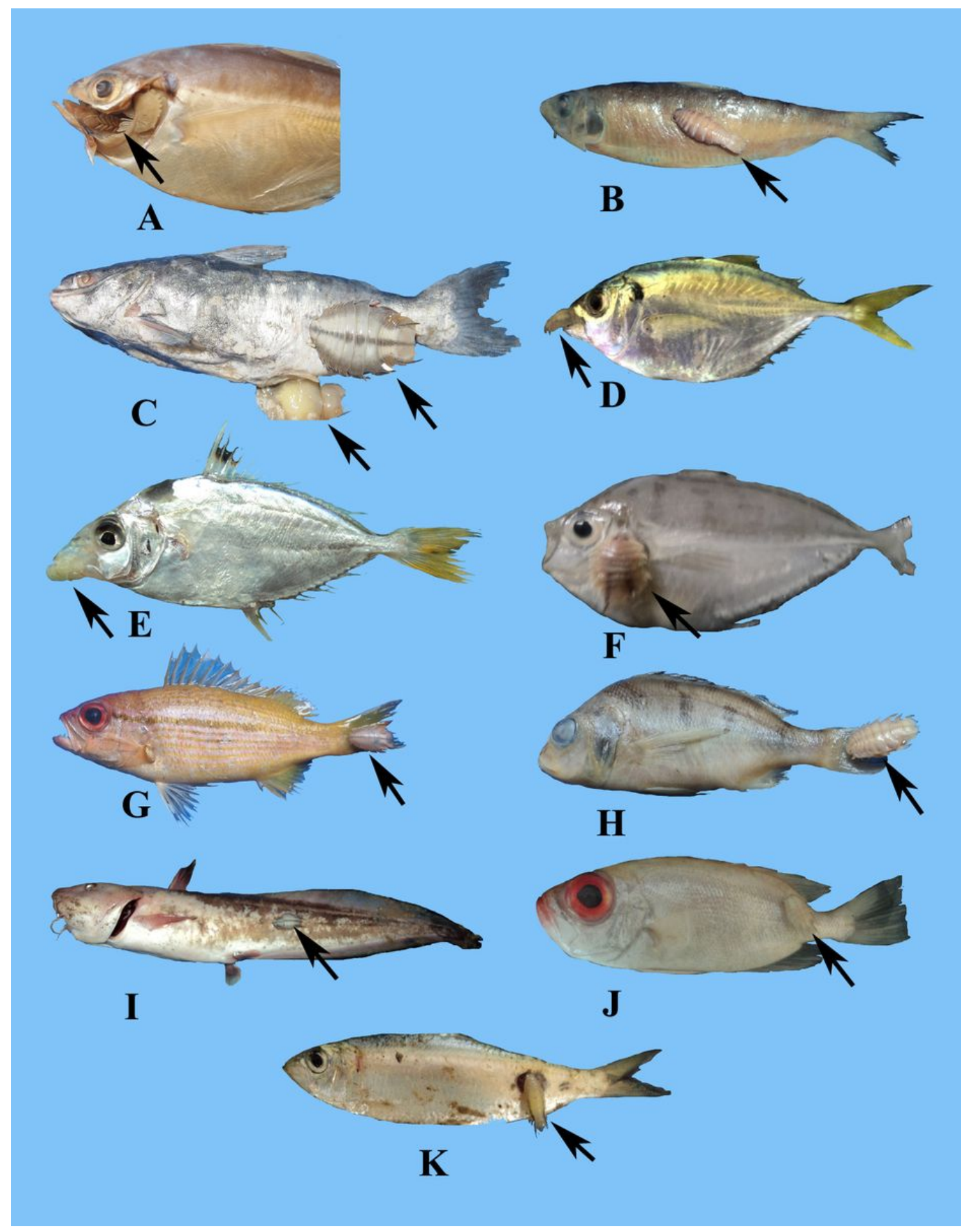

\section{Figure 2}

Host fish species and their parasites, (A) Catoessa boschii on Alepes djedaba, (B) Anilocra dimidiate on Sardinella longiceps, (C) Nerocila serra on Arius arius, (D) C. boschii on Alepes kleinii, (E) C. boschii on Leiognathus blochii. (F) N. loveni on Deveximentum insidiator, (G) N. sigani on Lutjanus lutjanus, $(H) N$. serra on Nibea maculate, (I) N. serra on Plotosus lineatus, (J) N. sigani on Priacanthus tayneus, (K) N. depressa on Sardinella gibbosa 


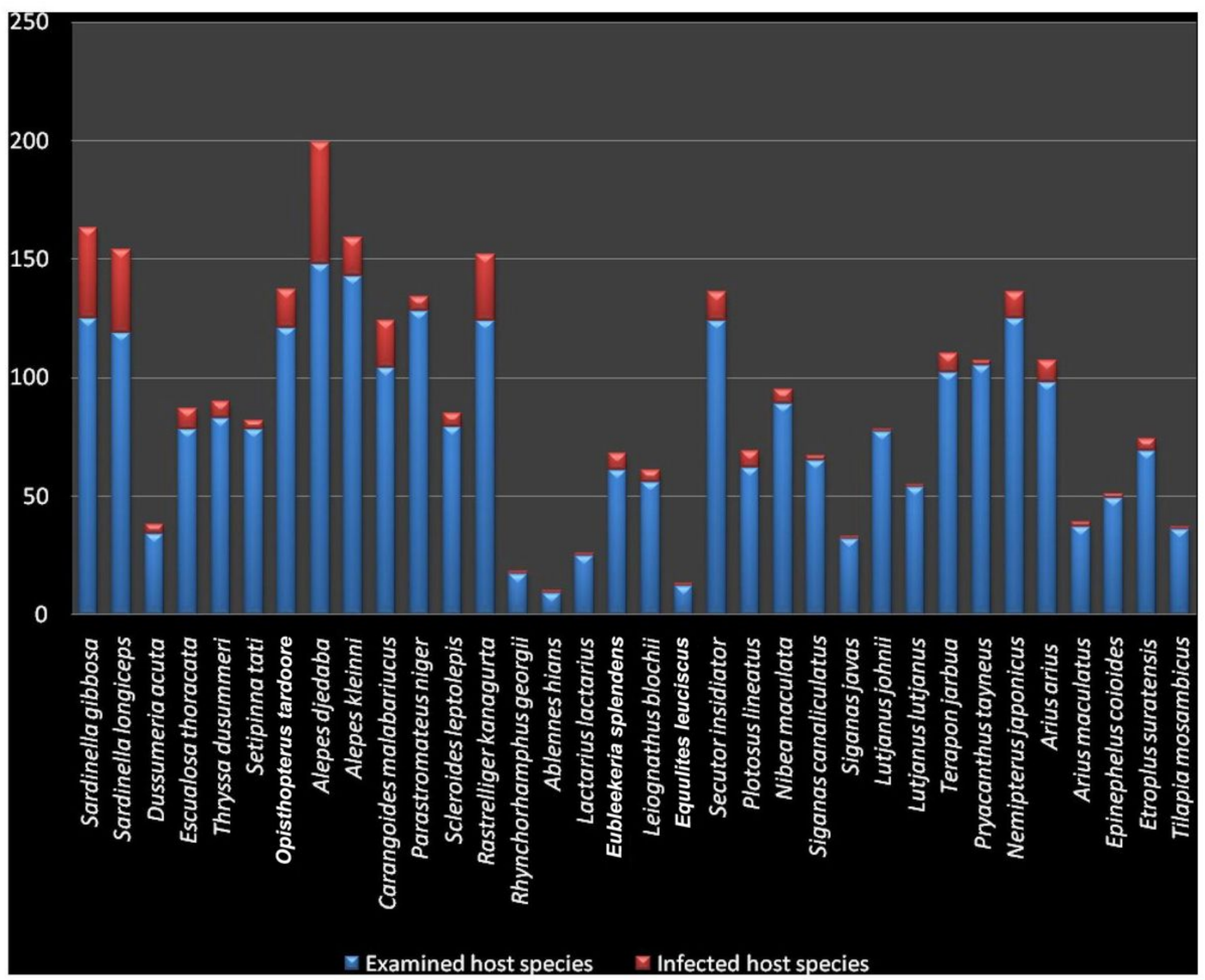

Figure 3

Number of fish species examined and parasitized by isopods during the study 


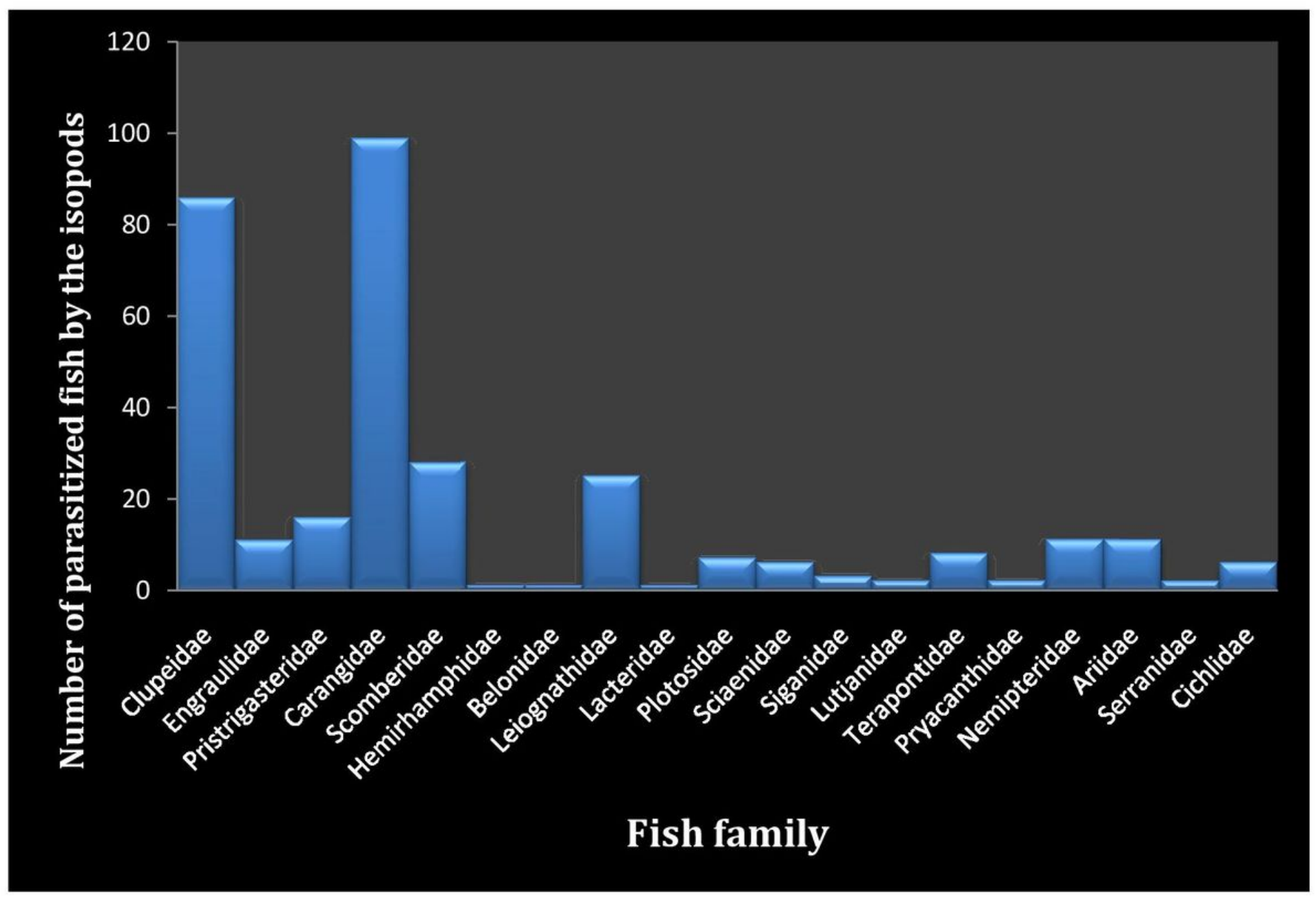

Figure 4

Fish (family-wise) isopod infection 


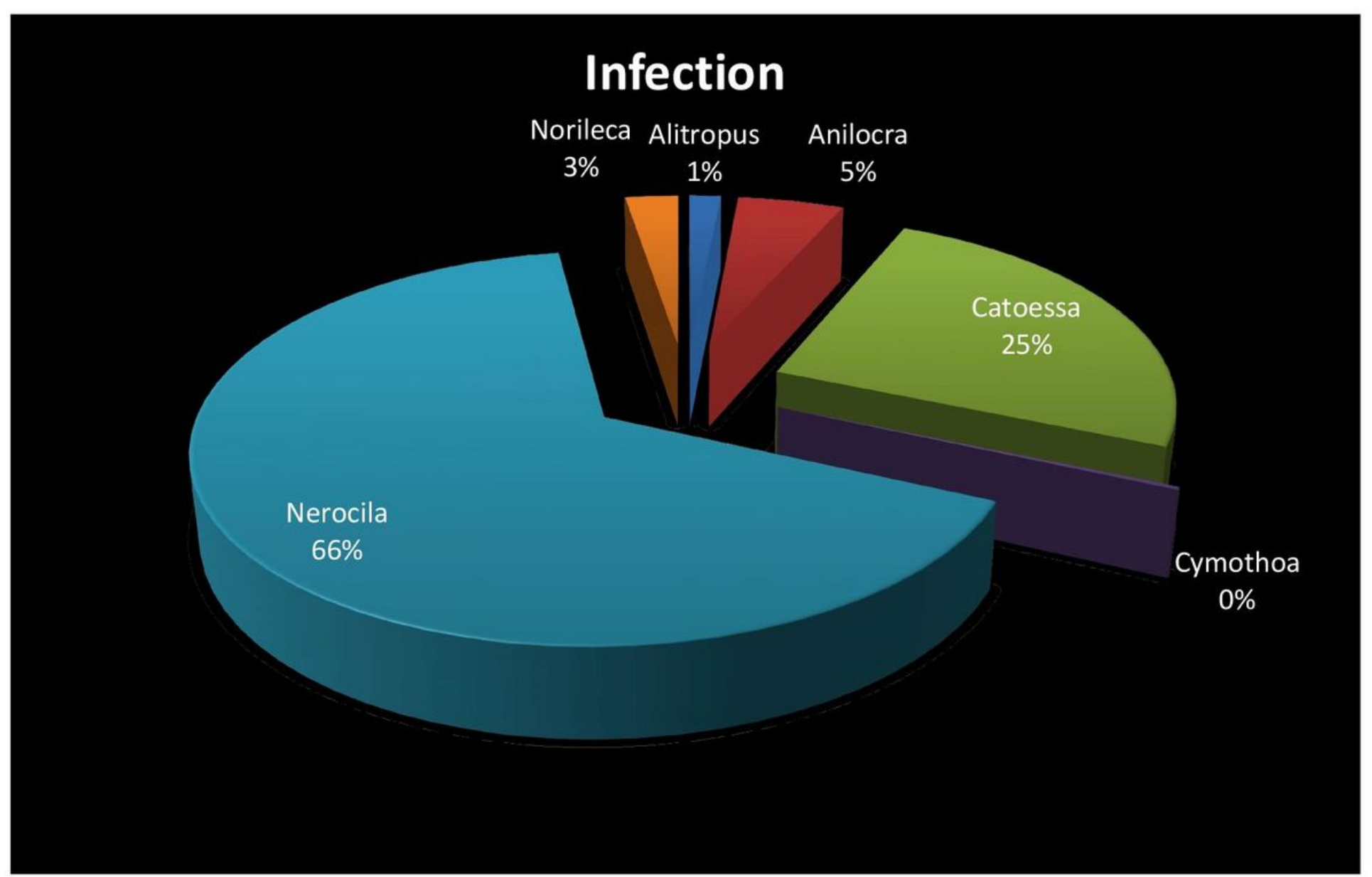

Figure 5

Pie chart of isopod (genus-wise) infecting the fish species during the study period 


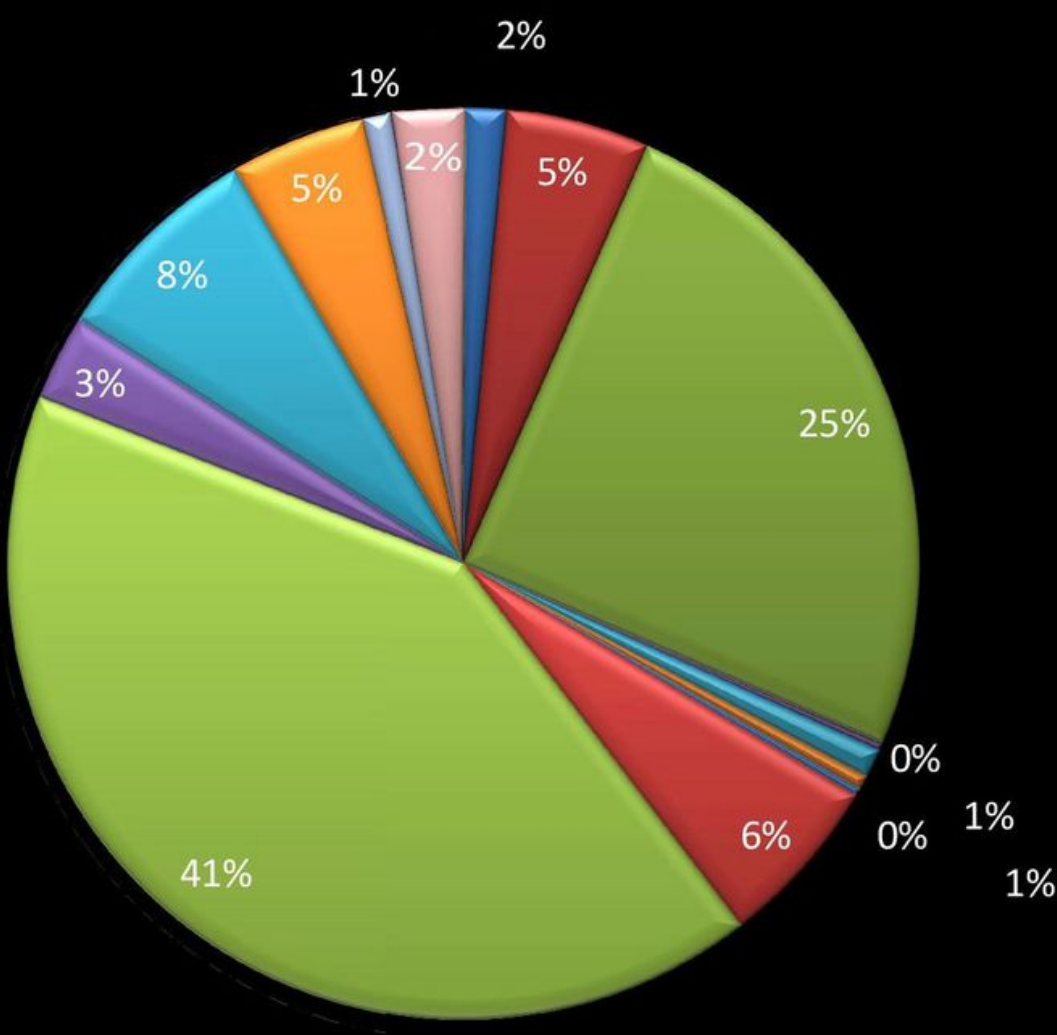
× Alitropus typus
- Anilocra dimidata
- Catoessa boscii
- Cymothoa eremita
- Nerocila depressa
\$ $N$. exocoeti
\ $N$. longispina
M. loveni
- N.phaopleura
- N purovae
m $N$ serra
× $N$ sigani
ॠ $N$. sundica
\Norileca indica

\section{Figure 6}

Pie chart of isopod (species wise) infecting the fish species during the study period

\section{Number}

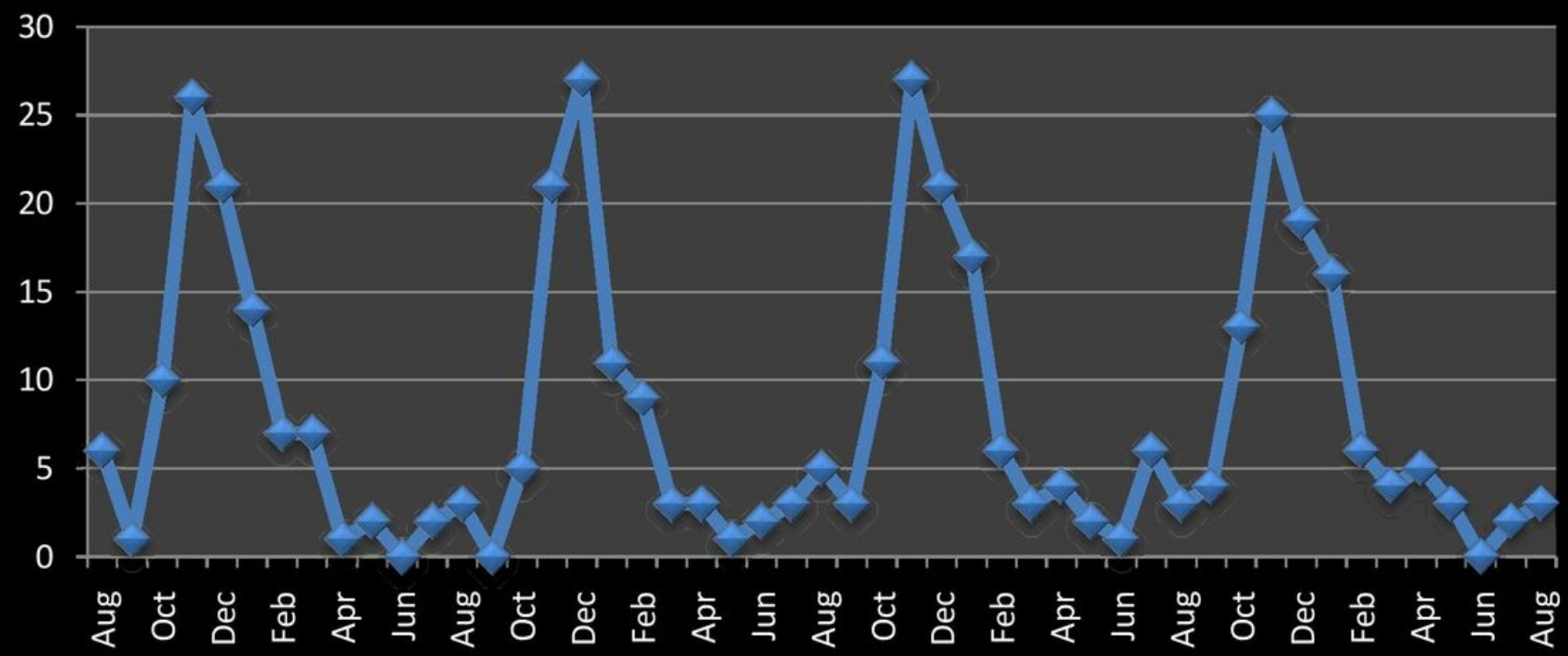


Figure 7

Seasonal variation of parasitic infection during the study period 